http://ejtr.vumk.eu

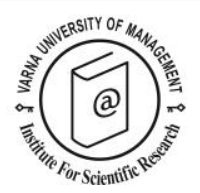

\title{
Effects of green practices on guest satisfaction and loyalty
}

\author{
Mihaela-Simona Moise ${ }^{1}$, Irene Gil-Saura ${ }^{2}$ and María-Eugenia Ruiz-Molina ${ }^{3 *}$
}

Received: 22/03/2018 Accepted: 25/06/2018

\footnotetext{
${ }^{1}$ Department of Marketing, Faculty of Economics, University of Valencia, Avda. Naranjos, s/n, 46022 Valencia, Spain. E-mail: Mihaela.Moise@uv.es Phone: +34 963828312

2 Department of Marketing, Faculty of Economics, University of Valencia, Avda. Naranjos, s/n, 46022 Valencia, Spain. E-mail: Irene.Gil@uv.es Phone: +34 963828329

3 Department of Marketing, Faculty of Economics, University of Valencia, Avda. Naranjos, s/n, 46022 Valencia, Spain. E-mail: M.Eugenia.Ruiz@uv.es Phone: +34 961625177

* Corresponding author
}

\begin{abstract}
Due to the growing awareness of consumers about the seriousness of environmental problems and the importance of environmental protection, more and more hotel companies have been developing green practices to respond to this environmental concern of customers. This paper proposes and tests the relationship between these "green" initiatives and the satisfaction of tourists and their intentions to return and their willingness to spread a positive word-of-mouth (WOM) of the hotel. In order to compare the hypotheses proposed, the methodology of the survey is used through a structured questionnaire based on the information provided by guests staying in 3 and 4-star hotels. The results show that there is a positive relationship between "green" practices and customer satisfaction, and in turn provides evidence of the effect of environmental measures, both direct and mediated through satisfaction, on the intention to return and the WOM developed by guests. Moreover, the motive of the trip plays a moderating role in the relationship between hotel "green practices" and guest satisfaction. Our work highlights the importance of the hotel companies' implementation of sustainable practices to meet the needs of their clients and the attainment of favourable attitudes towards their intention to return.
\end{abstract}

(C) 2018 Varna University of Management. All rights reserved

Keywords: Green practices; satisfaction; WOM; intention to return; trip purpose

Citation: Moise, M.S., I. Gil-Saura, M.E. Ruiz-Molina (2018) Effects of green practices on guest satisfaction and loyalty. European Journal of Tourism Research 20, pp. 92-104

\section{Introduction}

In recent years the environmental impact of the growing holiday industry has become a vital issue (Legrand et al., 2016). According to the UN World Tourism Organisation (UNWTO, 2014), approximately $5 \%$ of total contaminating emissions on the planet are related to tourism, because hotels consume vast amounts of resources with detrimental effects for the environment (Kasim, 2004). As a result, for over ten years "green hotels"- defined as environmentally-friendly accommodation which helps to protect the environment with measures to save water and energy and reduce solid 
waste (Green Hotel Association, 2014) - have been seen as a long term trend and key to success in the holiday industry (Manaktola and Jauhari, 2007; Chan, 2013).

In addition, more recent research suggests that consumers are becoming increasingly aware of environmental problems and are therefore interested in purchasing "green" products and services (Han et al., 2009; Chan, 2013). According to the results of a survey conducted by Trip Advisor, $79 \%$ of interviewees chose to stay at hotels with environmentally-friendly practices (Trip Advisor, 2013), showing that in the hotel industry, tourists prefer to stay at hotels which are taking measures to protect the environment in order to contribute to environmental sustainability (Han et al., 2010).

Although numerous studies have focused on analysing consumer satisfaction and loyalty, so far, only a small number of articles have explored the effects of "green" practices applied by this type of tourism business on customer satisfaction and intention to stay at the establishment again and their willingness to spread positive word-of-mouth. These studies also report contradictory and inconclusive results (Han and Kim, 2010; Kim et al., 2012; Chen, 2015).

Moreover, the reason for the trip affects accommodation demand (Oh and Jeong, 2004), with tourists having higher leisure and relaxation expectations than business guests (Ariffin and Maghzi, 2012). In this sense, it would be relevant for hotel managers to find out if the reason for the trip may have a moderating role in the relationship between environmental practices and guest satisfaction and loyalty, in order to segment customers and develop specific actions for each guest profile.

The present study is intended to meet a twofold objective. Firstly, to cover a gap in current research, proposing and testing a model that provides greater understanding of the impact of sustainable practices on hotel guest satisfaction and loyalty. And secondly, to analyse the role of reason for the trip in the relationships between these variables. The results will offer information for hotel managers to focus their efforts on the aspects that will help them to maintain lasting relationships with customers and achieve competitive advantages.

\section{"Green" practices in hospitality}

The "green" concept that began to emerge in the 1990s is attracting increasing attention from both hotel owners and consumers (Chen et al., 2009; Han and Kim, 2010), achieving greater relevance in recent years because environmental sustainability has been identified as one of the most significant challenges facing the service industry in general and the hotel industry in particular (Sloan et al., 2013; Hall et al., 2016).

In the tourism literature, "green" practices have been defined as "internal efforts or activities of a hotel to implement environmentally friendly practices towards the goal of becoming a green facility" (Kim, 2005, p.9). Due to the nature of their services and functions, hotels consume large amounts of energy, water and nondurable goods, causing serious damage to the environment with their daily operations (Yue, 2012; Chen and Tung, 2014). For that reason, many hotel businesses have adopted a variety of environmentally-friendly practices - also called "green", ecological, sustainable, ecofriendly or environmentally responsible (Pizam, 2009)-, for example, to save water and energy and reduce solid waste (Manaktola and Jauhari, 2007; Green Hotels Association, 2014), product strategies (using organic or recycled products in their usual services and activities), changing systems and behaviours towards reuse and recycling of products and waste generated by the company in order to limit the negative impacts of their activities in natural and social environments and to make their business more sustainable (Claver-Cortés et al., 2007; Kim and Han, 2010; Han et al., 2010; Sloan et al, 2013; Jones et al., 2014).

Previous research has also shown that sustainable practices can have a significant impact on business competitiveness (Manaktola and Jauhari, 2007; Han et al., 2009). It has argued that consumers are increasingly concerned about climate changerelated problems and therefore frequently participate in eco-friendly activities in their daily life, seeking "green" products and services to 
Effects of green practices on guest satisfaction and loyalty.

contribute towards environmental sustainability (Chan, 2013).

Various studies note that tourists perceive certain environmental attributes as "basic" attributes (Robinot and Giannelloni, 2010) and are willing to give up some degree of comfort and luxury to support hotels that have adopted environmentally-friendly measures (Clark et al., 2003; Manaktola and Jauhari, 2007; Butler, 2008; Kim and Han, 2010) and even make some financial sacrifices (Stern, 2000). Sustainable measures adopted by hotel companies that tourists value the most include water and energy saving measures (Can et al., 2014). Other "green" practices positively assessed by hotel guests are recycling and reuse, reductions in the frequency of changing bed linen and towels, public transport and purchasing local products (Cleveland et al., 2005; Kasimu et al., 2012; Kim et al., 2012; Wang, 2012; Chen and Tung, 2014; Chen, 2015). In this sense, hotel businesses can benefit from publicising their environmental performance and offering detailed information on their environmentally-friendly activities (Tierney et al., 2011; Millar and Baloglu, 2011). In a similar vein, Constantin et al. (2013) point out that the presence of eco-certification has had a great impact on tourists' hotel choices. Indeed, customers' concern for the environment leads them to support hotels that have adopted "eco-friendly" practices in their daily activities (Manaktola and Jauhari, 2007) and increases their intention to stay at such establishments (Han et al., 2009; Han et al., 2011; Chen, 2015). Recent studies have shown that environmental initiatives are important factors in the choice of hotel (Tzschentkea, 2008; Kim et al., 2012).

Other studies, however, report that although consumers are aware of environmental issues, they do not consider "green" practices to be a priority when choosing where to stay and instead prefer conventional hotels (Kasim, 2004; Millar et al., 2012). Moreover, it has been argued that guests are often not aware that the establishment has an eco-certification (Fairweather et al., 2005), or even mistrust it (Furlow and Knott, 2009). Thus, when educating customers about environmental sustainability, it is important to develop effective communication strategies to encourage hotel guests to get involved in ecofriendly behaviour and an important concern for hotels is to increase the credibility of messages focused on "green" practices (Kim and Kim, 2014).

\section{Consequents of "green" practices in hospitality: satisfaction and loyalty}

Recent studies have examined the impact of hotel firms' environmental practices on guest satisfaction (Lee and Heo, 2009; Berezan et al., 2013; Gao and Mattila, 2014) and loyalty in terms of hotel revisit and intention to generate word-of-mouth (WOM) communications (Han and Kim, 2010; Ham and Han, 2013; Gao and Mattila, 2014; Chen, 2015).

Satisfaction has been considered a determinant factor in business success and is one of the concepts that has recently awoken most interest in the service industry in general and the hotel industry in particular. In the literature, satisfaction has been defined from a variety of cognitive and/or affective approaches. The cognitive perspective implies comparison between sacrifice (cost) and reward (benefits) consumers perceive during and after their service experience (Oliver, 1980; Chitty et al., 2007). In contrast, from an affective approach, satisfaction is defined as an affective response of differing intensity, focused on specific aspects of acquisition and/or consumption which take place when the customer evaluates the product and/or service (Giese and Cote, 2000). Thus satisfaction refers to the global affective response after the experience with the service (Oliver, 1980).

In the context of hotels, given that the services offered to customers are more than just accommodation itself, authors like Pizam and Ellis (1999, p.330) state that "satisfaction with a hospitality experience is a sum total of satisfactions with the individual elements or attributes of all the products and services that make up the experience".

Previous studies report that "green" initiatives can increase satisfaction if tourists perceive good quality service or that, rather than saving money, such initiatives are aimed at reducing the negative impact of daily activities on the 
environment, thereby helping society to combat climate change (Lee and Heo, 2009; Berezan et al., 2013; Gao and Mattila, 2014). In contrast, Robinot and Giannelloni (2010) argue that the contribution of hotel "green" practices to guest satisfaction depends on the type of action; in this sense, even if environmental friendly practices are in general positively evaluated, guests consider the reuse of sheets and towels as a "basic" attribute they expected from hotels and that the absence of that attribute negatively influenced their satisfaction. Furthermore, their study shows that if a hotel uses clean, renewable energy sources, customers consider it to be a "plus" attribute that increases their level of satisfaction.

In addition to satisfaction, customer loyalty is another objective for firms, especially in competitive environments like the holiday industry and is one of the most studied variables in the area of consumer behaviour. In the literature, loyalty is understood as a multidimensional construct with behavioural and attitudinal components. The behavioural perspective places the emphasis on past experience while the attitudinal perspective is based on future actions. Some authors like Oliver (1997) clearly take the behavioural approach, defining loyalty as the commitment to repeat purchase of a product or service in the future. In contrast, other authors consider that conceptualising loyalty purely from the behavioural perspective prevents differentiating loyal customers from customers that habitually purchase a product and service and so they add the attitudinal component that includes favourable attitude towards the supplier leading to intention to recommend to third parties (Zeithaml et al., 1996).

Loyalty and satisfaction are two closely related constructs, with satisfaction being considered as a positive determinant of consumer loyalty (Anderson and Srinivasan, 2003; Petrick, 2005; Rauyruen and Miller, 2007). Similarly, Lam et al. (2004) suggest that customers who feel satisfied with a service can be motivated to purchase it again and recommend it to others by positive word-of-mouth (WOM).

In the hotel context, mixed results have been reported for the relationship between the two variables. Thus, while some authors consider that satisfaction positively influences intention to stay in the hotel (Han et al., 2009; Han et al., 2011; Chen, 2015) and disseminate positive WOM (Lee and Heo, 2009; Han and Kim, 2010; Gao and Mattila, 2014), other studies, such as the study by Bajs (2015) provide evidence that tourists' future purchase intentions are not affected by their satisfaction. In view of the existing evidence, we posit:

H1: Hotels' "green" practices positively and significantly affect tourist satisfaction.

H2: Tourist satisfaction positively and significantly influences positive WOM.

H3: Tourist satisfaction positively and significantly influences hotel revisit intention.

Various studies have examined the effect of "green" practices on tourists' intention to revisit and disseminate positive WOM, drawing a variety of conclusions. Thus while certain environmental practices like the use of low energy light bulbs, soap and shampoo dispensers and recycling policy directly and positively influence hotel revisit and WOM intention (Han and Kim, 2010; Ham and Han, 2013; Gao and Mattila, 2014; Chen, 2015), other initiatives, like purchasing local and organic products, only has a positive impact on tourist satisfaction, not on revisit intention (Berezan et al., 2013). Therefore we posit:

H4: Hotels' "green" practices positively and significantly affect positive WOM.

H5: Hotels' "green" practices positively and significantly affect tourists' revisit intention

\section{Reasons for the trip}

For the purpose of this study, hotel guests are grouped into two categories: leisure and business. The literature has demonstrated differences between the two groups due firstly, to the nature of the trip ( $\mathrm{Ho}$ and McKercher, 2012) and secondly, to the fact that business travellers do not normally pay for their trips themselves (Lederman, 2007). Leisure guests are also more sensitive to policy and economic changes in their decision-making whereas business travellers do not have sufficient choice over whether to travel to a particular destination or not (Kucukusta et al., 2014). 
As mentioned above, hotel guests are becoming increasingly concerned about the environment and so they show increasing preference for environmentally-friendly products and services. The environmental attitudes of business and leisure guests have been evaluated in the context of "green" hotels with mixed results. In this sense, while some studies find that leisure guests consider themselves to be "more environmentally aware" (Crocker, 2008), others like Millar et al., (2012) suggest that although in their daily lives business guests are more concerned about the environment than leisure guests, when evaluating a hotel's environmental initiatives, there are no significant differences between the two groups. In contrast, business travellers are more frequently using hotel services than leisure travellers, that do not travel so frequently or may opt for other lodging options (e.g. camping, apartment, bed and breakfast, hostel), being pointed out that those consumers with a higher knowledge of green hotels and their practices are more likely to stay in them (Bastic and Gojcic, 2012).

In short, we consider there are differences between guests depending on the reason for the trip and therefore:

H6: Relationships between "green" practices, satisfaction, WOM and revisit intention respectively are stronger for leisure guests than business guests.

The relationships between the different constructs are shown in Figure 1.

\section{Methodology}

In order to investigate the proposed hypotheses, a quantitative study was conducted based on a structured questionnaire. The information was collected in the city of Valencia (Spain) by face-to-face survey of Spanish guests staying in three and four-star hotels for a final sample of 378 valid questionnaires. After a questionnaire pre-test with a small sample of hotel guests, data were collected between 15th May and 15th June 2016. Table 1 presents the main characteristics of the research.

All the study variables were measured by items that were proposed and adapted from the review of various studies in the literature. A 5point Likert type study was used (where 1= "totally disagree" and 5 "totally agree") for all the questionnaire items. Of the twenty-one items on "green" practices, twenty of them were taken from Can et al. (2014) adding a new item related to the hotel's eco-certification based on previous studies such as Millar and Baloglu (2011) and Constantin et al. (2013). Regarding these practices, respondents are asked to rate

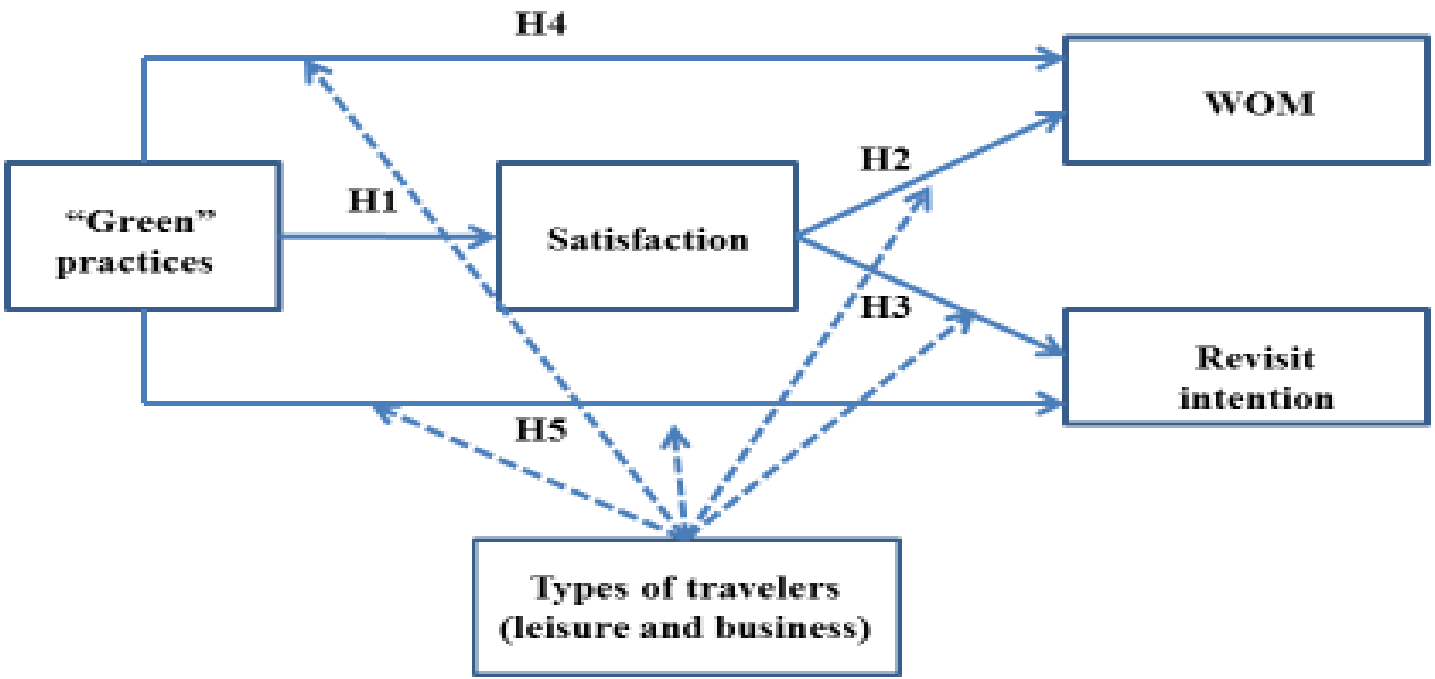

Figure 1. Research model 
Table 1. Research technical details

\begin{tabular}{ll}
\hline Universe & Customers of 3 and 4-star hotels, older than 18 \\
\hline Geographical scope & Valencia (Spain) \\
Sample size & 378 hotel guests (11 hotels) \\
Sample design & Face-to-face survey \\
Data collection period & $\begin{array}{l}15^{\text {th }} \text { May-15 } \\
\text { Descriptive analysis }\end{array}$ \\
Dtatistical techniques & $\begin{array}{l}\text { Confirmatory Factor Analysis } \\
\text { Structural Equations Mode } \\
\text { Multigroup analysis }\end{array}$ \\
IBM SPSS version 22.0 \\
Statistical software & EQS 6.2 \\
\hline
\end{tabular}

Table 2. Sample descriptive statistics

\begin{tabular}{llllllll}
\hline Gender & $\%$ & Age & $\%$ & Educational level & $\%$ & Income level (euro) & $\%$ \\
\hline Male & 49.8 & $18-25$ & 12.9 & Primary studies & 2.8 & $<12,000$ & 27.7 \\
Female & 50.2 & $26-35$ & 27.3 & Secondary studies & 37.7 & $12,001-18,000$ & 33.3 \\
\hline Occupation & $\%$ & $36-50$ & 28.5 & Higher education & 59.5 & $>18,000$ & 39.0 \\
\cline { 1 - 3 } Student & 13.3 & $51-65$ & 23.3 & & & & \\
Employee/employer & 76.3 & $>65$ & 8.0 & & & & \\
Other & 10.4 & & & & & & \\
\hline
\end{tabular}

from 1 to 5 the importance they assign to the green practices adopted by the hotel. Four items proposed by Williams and Soutar (2009) were used to measure satisfaction. And finally, four items were used to measure both hotel revisit and positive word-of-mouth intention, two for each variable, adapted from the scale proposed by Kim et al. (2009).

A quota-sampling method was adopted to ensure that a representative sample of hotel guests was obtained, based on age and educational level of tourists visiting Spain according to the last available report of the Spanish Ministry of Industry, Energy and Tourism (Instituto de Turismo de España, 2013). Table 2 shows the main sample descriptive statistics.

\section{Analysis of the results}

We decided to analyse the results in two stages. First, the measurement instrument was validated using Confirmatory Factor Analysis and second, the structural model was estimated. Both analyses were run using structural equations methodology with EQS 6.2 software.

The results in Table 3 mean scale reliability can be confirmed as both composed reliability and
Cronbach's alpha coefficient are above the recommended value of 0.7 (Nunnally and Bernstein, 1994) for all the constructs and standardised factor loads are statistically significant for all items. Scale convergent validity was assessed with the composite reliability index $(\mathrm{CRI})$ and analysis of variance extracted (AVE) finding that the values were above the thresholds established in the literature ( 0.7 and 0.5 respectively) (Fornell and Larcker, 1981). These findings allow us to confirm the model's convergent validity.

Discriminant validity was analysed applying two criteria: the test of variance extracted and the confidence interval test. The first test shows discriminant validity if the AVE of the factors exceed the square of the covariances (Fornell and Larcker, 1981). The second criterion involves calculating a confidence interval for the covariance \pm two standard errors for the correlation between two constructs. If the interval does not include the value 1, discriminant validity can be confirmed (Anderson and Gerbing, 1988). The data shown in Table 4 confirm the discriminant validity of the measurement model. 
Effects of green practices on guest satisfaction and loyalty.

Table 3. Confirmatory factor analysis results

\begin{tabular}{|c|c|c|c|c|c|c|}
\hline Construct & Measurement items & $\begin{array}{c}\begin{array}{c}\text { Standardized } \\
\text { factor } \\
\text { loading }\end{array} \\
\end{array}$ & t-value & CA & CR & AVE \\
\hline \multirow{22}{*}{$\begin{array}{l}\text { "Green" } \\
\text { practices }\end{array}$} & & & & 0.971 & 0.971 & 0.617 \\
\hline & & 0.748 & $16.973^{*}$ & & & \\
\hline & $\begin{array}{l}\text { Architectural design of hotel compatible with } \\
\text { natural environment }\end{array}$ & 0.767 & $17.818^{*}$ & & & \\
\hline & $\begin{array}{l}\text { Using electricity system which shuts down after } \\
\text { leaving the room (energy saving room keys) }\end{array}$ & 0.819 & $19.353^{*}$ & & & \\
\hline & Consumption of local food & 0.745 & $16.882^{*}$ & & & \\
\hline & Consumption of organic food & 0.740 & $16.729^{*}$ & & & \\
\hline & Preferring non-packaged goods & 0.806 & $18.887^{*}$ & & & \\
\hline & Using energy saving lighting facilities & 0.718 & $16.037^{\star}$ & & & \\
\hline & $\begin{array}{l}\text { Providing bulk soap and shampoo dispensers and } \\
\text { removing the individual bottles }\end{array}$ & 0.754 & $17.173^{*}$ & & & \\
\hline & $\begin{array}{l}\text { Using water saving showers, facets and flush } \\
\text { tanks }\end{array}$ & 0.740 & $16.714^{*}$ & & & \\
\hline & Having non-smoking room & 0.753 & $17.117^{*}$ & & & \\
\hline & $\begin{array}{l}\text { Developing an environmental recycling program, } \\
\text { using recycling bins } \\
\text { Informing quests about changing the sheets. }\end{array}$ & 0.773 & $17.769^{*}$ & & & \\
\hline & $\begin{array}{l}\text { Informing guests about changing the sheets, } \\
\text { pillow cases, towels in accordance to their } \\
\text { request }\end{array}$ & 0.752 & $17.096^{*}$ & & & \\
\hline & $\begin{array}{l}\text { Supplying electricity from renewable energy } \\
\text { resources }\end{array}$ & 0.784 & $18.154^{*}$ & & & \\
\hline & $\begin{array}{l}\text { Arranging environmental education programs and } \\
\text { activities for children }\end{array}$ & 0.746 & $16.892^{*}$ & & & \\
\hline & Encouraging guests to use public transportation & 0.804 & $18.835^{\star}$ & & & \\
\hline & \multirow{2}{*}{$\begin{array}{l}\text { Informing guests about water-saving at rooms } \\
\text { Informing guests about the environmental policy } \\
\text { of the hotel, encouraging guests in order to } \\
\text { participate in environmental efforts, considering } \\
\text { their ideas in environmental protection }\end{array}$} & 0.830 & $19.777^{*}$ & & & \\
\hline & & 0.815 & $19.239^{*}$ & & & \\
\hline & $\begin{array}{l}\text { Having efforts about marketing and protection of } \\
\text { cultural, historical and natural resources around } \\
\text { the hotel }\end{array}$ & 0.858 & $20.824^{*}$ & & & \\
\hline & $\begin{array}{l}\text { Informing guests about biological diversity around } \\
\text { the hotel }\end{array}$ & 0.858 & $20.837^{*}$ & & & \\
\hline & $\begin{array}{l}\text { Promoting environmental protection efforts of the } \\
\text { hotel in printed and visual media }\end{array}$ & 0.857 & $20.780^{*}$ & & & \\
\hline & The hotel is certified with Green Certification & 0.809 & $19.008^{*}$ & & & \\
\hline \multirow[t]{5}{*}{ Satisfaction } & \multirow{5}{*}{$\begin{array}{l}\text { Was exactly what I needed } \\
\text { I was satisfied with decision } \\
\text { It was a wise choice } \\
\text { It was a good experience }\end{array}$} & & & 0.958 & 0.958 & 0.852 \\
\hline & & 0.864 & $21.040^{*}$ & & & \\
\hline & & 0.918 & $23.303^{*}$ & & & \\
\hline & & 0.958 & $25.152^{*}$ & & & \\
\hline & & 0.949 & $24.714^{*}$ & & & \\
\hline \multirow[t]{3}{*}{ WOM } & & & & 0.986 & 0.986 & 0.972 \\
\hline & \multirow{2}{*}{$\begin{array}{l}\text { I would recommend this hotel to other people } \\
\text { I would tell other people positive things about this } \\
\text { hotel }\end{array}$} & 0.978 & $26.221^{*}$ & & & \\
\hline & & 0.994 & $27.062^{*}$ & & & \\
\hline \multirow[t]{3}{*}{$\begin{array}{l}\text { Revisit } \\
\text { intention }\end{array}$} & & & & 0.979 & 0.973 & 0.947 \\
\hline & \multirow{2}{*}{$\begin{array}{l}\text { I consider this hotel as my first choice compared } \\
\text { to other hotels } \\
\text { I have a strong intention to visit this hotel again }\end{array}$} & 0.959 & $25.245^{*}$ & & & \\
\hline & & 0.987 & $27.343^{*}$ & & & \\
\hline Goodness-of & Fit Statistics & & & & & \\
\hline & BBNNFI CFI & IFI & & RMSEA & & \\
\hline 1357.902 & $0.893 \quad 0.908$ & 0.909 & & 0.08 & & \\
\hline
\end{tabular}

Note: $\mathrm{CA}=$ Cronbach's Alpha, $\mathrm{CR}=$ Composite reliability, $\mathrm{AVE}=$ Average variance extracted

${ }^{*} p<0.05$ 
Table 4. Discriminant validity

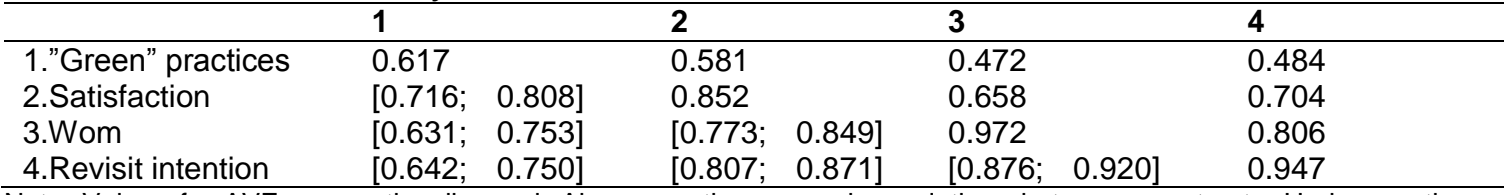

Note: Values for AVE are on the diagonal. Above are the squared correlations between constructs. Under are the confidence interval (ttwo standard errors) around the correlation estimate between the two factors.

Table 5. Structural equations model results

\begin{tabular}{|c|c|c|c|}
\hline Hypothesis & $\begin{array}{c}\text { Standardized } \\
\text { beta }\end{array}$ & t value & Decision \\
\hline H1: "Green" practices $\rightarrow$ Satisfaction & 0.764 & $14.011^{*}$ & Supported \\
\hline H2: Satisfaction $\rightarrow$ WOM & 0.737 & $13.700^{*}$ & Supported \\
\hline H3: Satisfaction $\rightarrow$ Revisit intention & 0.776 & $14.845^{\star}$ & Supported \\
\hline H4: "Green" practices $\rightarrow$ WOM & 0.125 & $2.565^{\star}$ & Supported \\
\hline H5: "Green" practices $\rightarrow$ Revisit intention & 0.106 & $2.328^{*}$ & Supported \\
\hline \multicolumn{4}{|l|}{ Goodness-of-Fit Statistic } \\
\hline $\begin{array}{l}X^{2} \\
1.429,653\end{array}$ & $\begin{array}{l}\text { CFI } \\
0.893\end{array}$ & 893 & $\begin{array}{l}\text { RMSEA } \\
0.087\end{array}$ \\
\hline
\end{tabular}

Note: ${ }^{*} p<0.05$

Table 6: Multigroup analysis results

\begin{tabular}{lllll} 
Hypothesis & $\begin{array}{l}\text { Group 1 } \\
\text { Leisure } \\
\mathbf{N = 1 9 2}\end{array}$ & $\begin{array}{l}\text { Group 2 } \\
\text { Business } \\
\mathbf{N = 1 8 4}\end{array}$ & Dif. $\mathbf{X}^{\mathbf{2}}$ & p-value \\
\hline H1: "Green" practices $\rightarrow$ Satisfaction & 0.749 & 0.813 & 13.826 & $0.000^{*}$ \\
H2: Satisfaction $\rightarrow$ WOM & 0.773 & 0.739 & 0.531 & 0.466 \\
H3: Satisfaction $\rightarrow$ Revisit intention & 0.821 & 0.825 & 2.692 & 0.101 \\
H4: "Green" practices $\rightarrow$ WOM & 0.106 & 0.110 & 0.078 & 0.780 \\
H5: "Green" practices $\rightarrow$ Revisit intention & 0.069 & 0.076 & 0.314 & 0.575 \\
\hline
\end{tabular}

Note: Goodness-of-Fit Statistic: $\mathrm{X}^{2}=2.789,145 ; \mathrm{BBNNFI}=0.893 ; \mathrm{CFI}=0.905 ;$ RMSEA=0.085;

${ }^{*} \mathrm{p}<0.001$

After confirming model validity, we estimated the structural equations model in Figure 1 with the results shown in Table 5 .

The results show that hotel's "green" practices have a significant, positive impact on guest satisfaction as well as on WOM and revisit intention respectively, and so hypotheses $\mathrm{H} 1$, $\mathrm{H} 4$ and $\mathrm{H} 5$ are accepted.

The results of studying the effects of satisfaction on customers' future intentions show that the intention to stay at the hotel again and to disseminate positive WOM depend positively and significantly on satisfaction, thereby confirming hypotheses $\mathrm{H} 2$ and $\mathrm{H} 3$.

In addition, according to hypothesis $\mathrm{H} 6$, we expected to find significant differences in the relationships between the constructs depending on the reason for the trip (leisure/business). To test this hypothesis, a multigroup analysis was conducted using the Chi-square difference test. For this test, the restriction that factor loads had to be equal in both sub-samples was introduced, and the Chisquare value of the restricted model was compared with that of the unrestricted model. If the difference is significant, it can be stated that the reason for the trip has a moderating effect. The results are shown in Table 6.

The results show only significant differences for intensity of the relationship between "green" practices and satisfaction which is stronger for business guests than leisure guests $(p<0.001)$, unlike the findings reported by Crocker (2008). One possible explanation could be the fact that in their daily lives, business guests are more concerned about the environment than leisure 
guests (Millar et al., 2012) and consequently are also more satisfied with environmental measures introduced in the hotels where they stay.

\section{Conclusions}

In this work, we aimed to shed additional light on the extant discussion in the literature about the relations between "green" practices and consumer satisfaction and loyalty in the hotel context, analysing the moderating role of reason for the trip in these relations. In this regard, first, the results provide evidence supporting the notion that hotel environmental measures can increase guest satisfaction, leading to a significant, positive relationship between "green" practices and customer satisfaction as some previous studies also report (Hu et al., 2011; Berezan et al., 2013; Gao and Mattila, 2014), thus providing evidence about the favourable contribution of hotel environmental friendly actions to guest satisfaction, in contrast to Robinot and Giannelloni (2010). Hotel managers should therefore increase efforts to ensure good quality service, actively informing customers of the positive consequences of their environmental actions, ensuring that the customer experience is not negatively impacted by the introduction of "green" practices.

Secondly, this study has analysed the relationship between hotels' environmentally friendly actions and the loyalty of their guests. Consistently with some previous studies arguing the existence of a positive relation between hotel green practices and guest loyalty (Lee and Heo, 2009; Han and Kim, 2010; Lee et al., 2011; Gao and Mattila, 2014), the present study confirms that environmental practices are positively related to willingness to disseminate positive WOM and hotel revisit intention. In other words, our results support the importance of introducing environmentally friendly measures to add value to the experience of staying at the hotel, generating customer satisfaction which will lead to a willingness to disseminate positive comments on the establishment and also to stay there again.

Thirdly, our analysis confirms the positive, significant relationship between tourist satisfaction and loyalty to the establishment. These results are in line with previous studies (Lee et al., 2011; Gao and Mattila, 2014), which show that satisfied guests can be motivated to return to the hotel on future trips and disseminate positive WOM.

Finally, the reason for the journey moderates the strength of the relation between "green practices" and guest satisfaction, in the sense that the positive effect of the hotel environmental practices is stronger for business travellers in comparison to tourists. This result may be explained by the higher educational and income levels of business travellers, in the line of previous studies pointing out that environmentally concerned tourists tend to be more educated (Hvenegaard and Dearden, 1998; Fairweather et al., 2005; Leonidou et al., 2015) and show higher income levels (Ballantine and Eagles, 1994; Eagles and Cascagnette, 1995; Leonidou et al., 2015) than the general population of tourists.

In contrast, the reason for the journey does not appear to play a significant moderating role in the relationships between "green" practices and guest loyalty. These results are consistent with those reported by Millar et al. (2012) in the sense that there are no major differences as regards loyalty and acceptance of the hotel's "green" initiatives in relation to a guest's reasons for the trip and they suggest that hotel managers do not necessarily need to differentiate between two types of travellers when they market their products and secondly, that any type of hotel can include environmentally friendly measures at its facilities.

From these findings several implications for management can be drawn. Given the growing competition in the hotel industry, establishments should begin differentiation strategies to maintain competitiveness. Hotel managers must be aware of the importance of introducing and further developing environmentally friendly practices in their establishments to enhance customer satisfaction and consequently to increase the likelihood of them returning to stay at the hotel and promoting positive WOM. Given the growing responsibility on the part of tourists, 
marketing actions should be focused therefore, not only on improving the quality of the services but also on incorporating "green" practices that can satisfy customers' social needs. Hotel companies must also actively demonstrate their commitment to the environment on their websites or through informal education tools, like leaflets, and thus advertise their concern for environmental well-being. They also need to invest in technologies that encourage and facilitate recommendations from satisfied customers, stimulating the dissemination of positive assessments. All of the above would favour positive WOM which would help to improve the hotel's image and attract new customers.

Notwithstanding, some limitations may be highlighted that can be regarded as possible future lines of research. Firstly, the restricted geographical scope of this study needs to be widened so the results can be compared with consumer perceptions in other geographical areas. The study could also be applied to other types of holiday establishments like guesthouses or campsites to check whether the same relationships are maintained between the variables. Finally, other relevant variables could be introduced in the model, like environmental activities carried out by customers in their daily lives, prior experience of "green" hotels and the influence of tourists' personal characteristics on the studied variables in the proposed model.

Acknowledgement: The authors are very grateful for the support of the project ECO2016-76553-R of the Spanish Ministry of Economy, Industry and Competitiveness. State Research Agency.

\section{References}

Anderson, J. C., and Gerbing, D. W. (1988). Structural equation modeling in practice: $A$ review and recommended two-step approach. Psychological Bulletin, 103(3), 411-423.

Anderson, R., and Srinivasan, S. (2003). Esatisfaction and e-loyalty: a contingency framework. Psychology \& Marketing, 20(2), 123-138.

Ariffin, A. A.M., and Maghzi, A. (2012). A preliminary study on customer expec- tations of hotel hospitality: Influences of personal and hotel factors. International Journal of Hospitality Management, 31(1), 191-198.

Bajs, I.P. (2015). Tourist perceived value, relationship to satisfaction, and behavioral intentions the example of the Croatian tourist destination Dubrovnik. Journal of Travel Research, 54 (1), 122-134.

Ballantine, J. L., and Eagles, P. F. J. (1994). Defining Canadian ecotourists. Journal of Sustainable Tourism, 2, 210-214.

Bastic, M. and Gojcic, S. (2012). Measurement scale for eco-component of hotel service quality. International Journal of Hospitality Management, 31 (3), 1012-1020.

Berezan, O., Raab, C., Yoo, M., and Love, C. (2013). Sustainable hotel practices and nationality: The impact on guest satisfaction and guest intention to return. International Journal of Hospitality Management, 34, 227-233.

Butler, J. (2008). The compelling "hard case" for green hotel development. Cornell Hotel and Restaurant Administrative, 49, 234244.

Can, A.S., Turker, N., Ozturk, S., and Alaeddinoglu, F. (2014). Tourists perceptions of Green practices in ecofriendly hotels: a case study from the Antalya region of Turkey. Journal of Tourism Challenges and Trends, 7(1), 926.

Chan E.S.W. (2013). Gap analysis of green hotel marketing. International Journal of Contemporary Hospitality Management, 25(7), 1017-1048.

Chen, J.S., Sloan, P. and Legrand, W. (2009). Sustainability in the hospitality industry. Maryland Heights, MO: Elsevier.

Chen, M. F., and Tung, P. J. (2014). Developing an extended Theory of Planned Behavior model to predict consumers' intention to visit green hotels. International Journal of Hospitality Management, 36, 221-230.

Chen, R.J. (2015). From sustainability to customer loyalty: A case of full service hotels' guests. Journal of Retailing and Consumer Services, 22, 261-265.

Chitty, B., Ward, S., and Chua, C. (2007). An application of the ECSI model as a predictor of satisfaction and loyalty for 
backpacker hostels. Marketing Intelligence \& Planning, 25(6), 563-580.

Clark, C. F., Kotchen, M. J., and Moore, M. R. (2003). Internal and external influences on pro-environmental behavior: Participation in a green electricity program. Journal of Environmental Psychology, 23(3): 237246.

Claver-Cortés, E., Molina-Azorín, J. F., PereiraMoliner, J., and López-Gamero, M. D. (2007). Environmental strategies and their impact on hotel performance. Journal of Sustainable Tourism, 15(6), 663-679.

Cleveland, M., Kalamas, M., and Laroche, M. (2005). Shades of green. Journal of Consumer Marketing, 22(4/5), 198-212.

Constantin, C.P., Ispas, A., and Candrea, A.N. (2013). Identifying Tourists Interested in Eco-Certified Accommodation Units from Brașov, Romania. Management Dynamics in the Knowledge Economy, 1(3), 521542.

Crocker, M. (2008). Among leisure travelers surveyed, nearly everyone professes to be green http://apps.travelweekly.com/Multi media/consumertrends072808/index.html.

Eagles, P. F. J., and Cascagnette, J. W. (1995). Canadian ecotourists: Who are they? Tourism Recreation Research, 20, 22-28.

Fairweather, J. R.,Maslin, C. and Simmons, D. G. (2005). Environmental values and response to eco-labels among international visitors to New Zealand. Journal of Sustainable Tourism, 13 (1), 82-98.

Fornell C., and Larcker, D. F. (1981). Evaluating structural equation models with unobservable variables and measurement error. Journal of Marketing Research, 18(1), 39-50.

Furlow, N., and Knott, C., (2009). Who's reading the label? Millenials' use of environmental product labels. Journal of Applied Business and Economics. 10(3), 1-12.

Gao, Y.L., and Mattila A.S. (2014). Improving consumer satisfaction in green hotels: The roles of perceived warmth, perceived competence, and CSR motive. International Journal of Hospitality Management, 42, 20-31.
Giese, J.L., and Cote, J.A. (2000). Defining Customer Satisfaction. Academy of Marketing Science Review, 2000(1), 1-34.

Green Hotel Association, (2014). Why Should Hotels be Green? URL: http://www.green hotels.com (Accessed on 22.03.2018).

Hall, C. M., Dayal, N., Majstorović, D., Mills, H., Paul-Andrews, L., Wallace, C., and Truong, V. D. (2016). Accommodation consumers and providers' attitudes, behaviours and practices for sustainability: A systematic review. Sustainability, 8(7), 625.

Ham, S., and Han, H. (2013). Role of perceived fit with hotels' green practices in the formation of customer loyalty: Impact of environmental concerns. Asia Pacific Journal of Tourism Research, 18(7), 731748.

Han, H., Hsu, L., and Lee, J. (2009). Empirical investigation of the roles of attitudes toward green behaviors, overall image, gender, and age in customers' ecofriendly decision-making process. International Journal of Hospitality Management, 28(4), 519-528.

Han, H., Hsu, L., and Sheu, C. (2010). Application of the theory of planned behavior to green hotel choice: testing the effect of environmental friendly activities. Tourism Management, 31, 325-334.

Han, H., Hsu, L.T.J., Lee, J.S., and Sheu, C. (2011). Are lodging consumers ready to go green? An examination of attitudes, demographics and eco-friendly intentions. International Journal of Hospitality Management, 30, 345-355.

Han, H., and Kim, Y. (2010). An investigation of Green hotel customers' decision formation: developing an extended model of theory of planned behavior. International Journal of Hospitality Management, 29(4), 659-668.

Ho G., and McKercher, B. (2014). A comparison of long-haul and short-haul business tourists of Hong Kong. Asia Pacific Journal of Tourism Research, 19(3), 342-355.

$\mathrm{Hu}, \mathrm{N} ., \mathrm{Fu}, \mathrm{Y}$. , and Wang, Y. (2011). An empirical study on the dimensions of consumer perceived value in green hotels. Conference: International Conference on 
Management and Service Science - IEEE MASS, Wuhan, 12-14 August (pp. 1-4).

Hvenegaard, G. T., and Dearden, P. (1998). Ecotourism versus tourism in a Thai national park. Annals of Tourism Research, 25, 700-720.

Instituto de Turismo de España (2013). Informe Anual 2012. URL: http://estadisticas. tourspain.es/es-ES/estadisticas/egatur/ Anuales/Movimientos\%20Tur\%C3\%ADsti cos\%20en\%20Fronteras\%20(Frontur)\%20 y\%20Encuesta\%20de\%20Gasto\%20Tur\% C3\%ADstico\%20(Egatur)\%202012.pdf (Accessed on 22.03.2018)

Jones, P., Hillier, D., and Comfort, D. (2014). Sustainability in the global hotel industry. International Journal of Contemporary Hospitality Management, 26(1), 5-17.

Kasim, A. (2004). Socio-environmentally responsible hotel business: do tourists to Penang Island, Malaysia care? Journal of Hospitality \& Leisure Marketing, 11(4), 528.

Kasimu, A.B., Zaiton, S., and Hassan, H. (2012). Hotels Involvement in Sustainable Tourism Practices in Klang Valley, Malaysia. International Journal of Economics and Management, 6(1), 21 - 34.

Kim, S.H. (2005). An Investigation into Hotel Employees Perception of Green Practices. Master Thesis, University of Central Florida, USA.

Kim, Y., and Han, H. (2010). Intention to pay conventional-hotel prices at a green hotel e a modification of the theory of planned behavior. Journal of Sustainable Tourism, 18(8), 997-1014

Kim, S. B., and Kim, D. Y. (2014). The effects of message framing and source credibility on green messages in hotels. Cornell Hospitality Quarterly, 55(1), 64-75.

Kim, T.T., Kim, W.G., and Kim, H.B. (2009). The effects of perceived justice on recovery satisfaction, trust, word-ofmouth, and revisit intention in upscale hotels. Tourism Management, 30(1), 5162.

Kim, Y.J., Palakurthi, R., and Hancer, M. (2012). The environmentally friendly programs in hotels and customers' intention to stay: An online survey approach. International Journal of
Hospitality \& Tourism Administration, 13(3), 195-214.

Kucukusta, D., Heung, V.C., and Hui, S. (2014). Deploying self-service technology in luxury hotel brands: Perceptions of business travelers. Journal of Travel and Tourism Marketing, 31, 55-70.

Lam, S.Y., Shankar, V., Erramilli,, M.K. and Murthy, B. (2004). Customer value, satisfaction, loyalty, and switching costs: an illustration from a business-to-business service context. Journal of the Academy of Marketing Science, 32(3), 293-311.

Lederman, M. (2007). Do enhancements to loyalty programs affect demand? The impact of international frequent flyer partnerships on domestic airline demand. The RAND Journal of Economics, 38, 1134-1158.

Lee, M., Han, H. and Willson, G. (2011). The Role of Expected Outcomes in the Formation of Behavioral Intentions in the Green-Hotel Industry. Journal of Travel \& Tourism Marketing, 28 (8), 840-855.

Lee, S., and Heo, C.Y. (2009). Corporate social responsibility and customer satisfaction among US publicly traded hotels and restaurants. International Journal of Hospitality Management, 28(4), 635-637.

Legrand, W., Sloan, P., and Chen, J. S. (2016). Sustainability in the hospitality industry: Principles of sustainable operations. Oxford: Routledge.

Leonidou, L. C., Coudounaris, D. N., Kvasova, O., and Christodoulides, P. (2015). Drivers and outcomes of green tourist attitudes and behavior: sociodemographic moderating effects. Psychology \& Marketing, 32(6), 635-650.

Manaktola, K., and Jauhari, V. (2007). Exploring consumer attitude and behaviour towards green practices in the lodging industry in India. International Journal of Contemporary Hospitality Management, 19(5), 364-377.

Millar, M., and Baloglu, S. (2011). Hotel guests' preferences for green guest room attributes. Cornell Hospitality Quarterly, 52(3), 302-311.

Millar, M., Mayer, K.J., and Baloglu, S. (2012). Importance of Green Hotel Attributes to Business and Leisure Travelers. Journal 
of Hospitality Marketing \& Management, 21(4), 395-413.

Nunnally, J. C., and Bernstein, I. H. (1994). Psychometric theory (3rd ed.). New York: McGraw-Hill.

Oh, H., and Jeong, M. (2004). Moderating effects of travel purpose and past experience on the relationship between product performance and lodging repurchase. Journal of Hospitality Marketing \& Management, 11(2/3), 139158.

Oliver, R.L. (1980). A Cognitive Model of the Antecedents and Consequences of Satisfaction Decisions. Journal of Marketing Research, 17(4), 460-469.

Oliver, R. L. (1997). Satisfaction: A behavioral perspective on the consumer. New York: Mc-Graw-Hill.

Petrick, J.F. (2005). Reoperationalising the loyalty framework. Tourism and Hospitality Research, 5(3), 199-212.

Pizam, A. (2009). Green hotels: A fad, ploy or fact of life? International Journal of Hospitality Management, 28(1).

Pizam, A., and Ellis, T. (1999). Customer satisfaction and its measurement in hospitality enterprises. International Journal of Contemporary Hospitality Management, 11(7), 326-339.

Rauyruen, P., and Miller, K. E. (2007). Relationship quality as a predictor of $\mathrm{B} 2 \mathrm{~B}$ customer loyalty. Journal of Business Research, 60(1), 21-31.

Robinot, E., and Giannelloni, J.L. (2010). Do hotels' "green" attributes contribute to customer satisfaction? Journal of Services Marketing, 24(2), 157 - 169.

Sloan, P., Legrand, W., and Chen, J.S. (2013). Sustainability in the hospitality industry (2nd ed.). New York, NY: Routledge.
Stern, P. C. (2000). New environmental theories: toward a coherent theory of environmentally significant behavior. Journal of Social Issues, 56(3), 407-424.

Tierney, P., Hunt, M., and Latkova, P. (2011). Do travelers support green practices and sustainable development? Journal of Tourism Insights, 2(2), 1-17.

TripAdvisor (2013). TripBarometer: The World's Largest Traveler and Accommodation Survey. URL: http://www.tripadvisortripbarometer (Accessed on 22.03.2018)

Tzschentkea, N.A. (2008). Going green: decisional factors in small hospitality operations. International Journal of Hospitality Management, 27(1), 126-133.

Wang, R. (2012). The investigation of Green Best Practices for Hotels in Taiwan. International Conference on Asia Pacific Business Innovation and Technology Conference, Procedia, Social and Behavioral Scieneces, 57: 140-155.

Williams, P., and Soutar, G.N. (2009). Value, Satisfaction and Behavioral Intentions in an Adventure Tourism Context. Annals of Tourism Research, 36(3), 413-438.

UNWTO - UN World Tourism Organization (2014). Responding to Climate Change Tourism Initiatives in Asia and the Pacific, UNWTO Publications. URL: https://www. e-unwto.org/doi/pdf/10.18111/97892844 16196 (Accessed on 23.06.2018).

Yue, Y.F. (2012). A research on environmental issues applied to the hotel industry. Advanced Materials Research, 430-432, 1159-1162.

Zeithaml, V.A., Berry, L.L., and Parasuraman, A. (1996). The behavioral consequences of service quality. Journal of Marketing, 60(2), 31-46. 